\title{
The Rule of Law as Political Philosophy
}

\author{
Gopal Prasad Dahal, PhD \\ Reader, Tribhuvan University \\ Email for correspondence: dahalgp@gmail.com
}

\begin{abstract}
In social science, rule of law indicates one of the most subjective and value loaded concepts. From the pragmatic vantage point, rule of law represents procedural device. This paper thus tried to appraise rule of law from philosophical perspectives. Based on literature review, my appraisal highlights that rule of law lays down under fundamental requirements for law by which those with power rule under the law. And for the citizen, the rule of law is both prescriptive (i.e. dictating the conduct required by law) and protective (i.e. demanding that government acts according to law) of the citizens. The notion of the rule of law is dependent upon the political foundations of a state that tailored to the concept upon a nation's economic resources. Here is why, rule of law must follow political philosophy or ancient/ modern natural law thought that corresponded good and equitable. And the rule of law must not to be confused with democracy, justice, equality (before the law or otherwise), human rights of any kind or respect for persons or for the dignity of the citizens. However, critical philosopher claimed that rule of law neither says about how the law is to be made by tyrants for democratic majorities nor says about ensuring fundamental rights and social justice. They also blamed that the rule of law is an ideological device engaged by those with power to mask the reality of that power in society, and the correlative powerlessness of the mass citizens.
\end{abstract}

Key words: Rule of law, constitution, government, citizen and political philosophy.

\section{Introduction}

The rule of law represents one of the most challenging concepts of the constitution. Where laws do not rule, there is no constitution (Aristotle, 1962). The rule of law is concept which is capable of different interpretations by different people, and it is this feature which makes an understanding of the philosophy elusive. Of all constitutional concepts, the rule of law is also the most subjective and value loaded. The apparent uncertainties in the rule of law and its variable nature should not cause concern, although, inevitably, it will cause some insecurity. In the study of the rule of law, it is more important to recognize and appreciate the many rich and varied interpretations which have been given to it, and to recognize the potential of the rule of law for ensuring limited government power and the protection of individual rights, than to be able to offer an authoritative, definitive explanation of the concept. The rule of law may be interpreted either as a philosophy or political theory which lays down fundamental requirements for law, or as a procedural device by which those with power rule under the law.

NUTA JOURNAL, 5 (1\&2), 2074 : ISSN: 2616 - 017x 
The essence of the rule of law is that of the sovereignty or supremacy of law over man. The rule of law insists that every person (i.e. irrespective of rank and status in society) be subject to the law. For the citizen, the rule of law is both prescriptive (i.e. dictating the conduct required by law) and protective (i.e. demanding that government acts according to law) of the citizens. This central theme recurs whether the doctrine is examined from the perspective of philosophy, or political theory, or from the more pragmatic vantage point of the rule of law as a procedural device. The rule of law underlies the entire constitution and, in one sense, all constitutional law is concerned with the rule of law. The concept is of great antiquity and continues to exercise legal and political philosophers today. The rule of law cannot be viewed in isolation from political society. The emphasis on the rule of law as yardstick for measuring both the extent to which government acts under the law and the extent to which individual rights are recognized and protected by law, is inextricably linked with Western democratic liberalism. In this respect, it is only meaningful to speak of the rule of law in a society which exhibits the features of democratically elected, responsible and responsive government and a separation of powers, which will result in a judiciary which is independent of government. In liberal democracies, therefore, the concept of rule of law implies an acceptance that law itself represents a good; that law and its governance is demonstrable asset to society (Barnett, 2004, p. 69).

\section{Contrasting Attitudes on Rule of Law}

It should not be assumed that this acceptance of law as a benevolent ruling force is universally accepted. In differing societies, subscribing to very different political philosophies, the insistence on the rule of law in the Western liberal sense has little application. For example, from a Marxist perspective the law serves not to restrict government and protect individual rights but rather to conceal the injustices inherent in the capitalist system. Accordingly, the concept of the rule of law, denoting some form of morality in law represents no more than a false idealization of law designed to reinforce the political structure and economic status quo in society. Echoes of this thesis dominate the more moderate socialist conceptions of the rule of law the critique of liberalism. It can be argued from the socialist perspective that liberalism pays too little regard to true equality between persons and great attention to the protection of property interests. The liberal domain thus becomes one which, again, masks true social and economic inequality while at the same time proclaiming equality and justice under the rule of law (Lustgarten, 1988, p.15).

The rule of law, as understood in liberal democracies, also found relevance in a totalitarian state. While it is true that such a state will be closely regulated by law, there will not be government under the law as adjudicated upon by an independent judiciary which is insisted upon under the liberal tradition.

The notion of the rule of law is dependent upon the political foundations of a state that tailored to the concept upon a nation's economic resources. It may be that law, as a mere regulator of individual behavior, is perfectly feasible in an impoverished state, and accordingly, a state which maintains law and order. And no more, can conform to a narrow interpretation of the rule of law which insists simply on a citizen's unquestioning compliance with rules of the law. However, if the rule of law implies more than mere regulation by law and is elevated to a theory guaranteeing freedom from hunger and homelessness and entitlement to a basic decent standard of life, then economic conditions are of paramount importance to conformity with the rule of law. Such an approach is adopted by the 
International Commission of Jurists, which in the New Delhi Declaration of 1959 included alongside traditional civil and political rights. The declaration realized social, economic, cultural and educational standards under which the individual could enjoy a fuller life within the ambit of the rule of law. One the other hand, reasoning such as this is anathema to radical conservatives such as Friedrich von Hayek (1944), who viewed the correct role of government as being best confined to establishing clear, fixed rules of law which ensure maximum economic freedom for individuals, unimpeded either by planning controls or ideas of redistributive justice. From von Hayek's perceptive, the rule of law requires no more than the existence of a stable set of minimum rules which are to be applied in a uniform, nondiscretionary manner. A legal system is viewed as just and in conformity with the rule of law, if it exhibits both these features and an absence of discretionary rules of practices.

\section{Uncertainty in the Western Rule of Law}

An understanding and appreciation of the rule of law is both politically and culturally dependent. Moreover, it is also clear that the rule of law has more than one meaning, even within the Western liberal tradition. To some theorists, the rule of law represents an aspiration philosophy; to others, no more than a device under which compliance with law good or bad in content is secured. It has been remarked that:

It would not be very difficult to show that the phrase 'the rule of law' has become meaningless thanks to ideological abuse and general over use (Shklar, 1987, p. 1). Partly as a result such overuse, some writers have refuted the claim that the rule of law represents anything other than a purely procedural or formalistic device. By way of example, Raz writes that, the rule of law says nothing about how the law is to be made: by tyrants, democratic majorities or any other way. It says nothing about fundamental rights, about equality, or justice (Raz, 1979, p. 210).

Contrast such views with that expressed in the following statement, the rule of law is a rare and protean principle of our political tradition. Unlike other ideals, it has withstood the ravages of constitutional time and remains a contemporary clarion-call to political justice. Apparently transcending partisan concern, it is embraced and venerated by virtually all shades of political opinion. The rule of law's central core comprises the enduring values of regularity and restraint, embodied in the slogan of 'a government of laws, not men (Hutchinson \& Monahan, 1987, p. 10). In light of such divergent assessments, it must be recognized that any attempt to align the rule of law with a broad philosophical doctrine or indeed with any other interpretation is likely to meet with opposition from some quarters. Not with standing such criticisms, the rule of law retains a secure grasp on political/legal thinking that has enduring importance as a central art a fact in our legal and political culture (Rax, 1979).

\section{The Rule of Law as Philosophical Doctrine}

The doctrine involves some considerable limitation on the powers of every political authority, except possibly (for this is open to dispute) those of a representative legislature. Jennings (1959) argued that it is an attitude, an expression of liberal and democratic principles becomes vague when it is sought to analyze them, but clear enough in their results. For Jennings, the doctrine implies, first, that the state as a whole must be regulated by law; secondly, that the separation of powers is implied within the doctrine in order to prevent dictatorship or absolutism. Accordingly, there are incorporated certain basic requirements of the law: equality before the law; clearly defined police powers; clear general rules adjudicated upon by the courts; non-retrospectively in penal statutes; and the strict construction 
of penal statutes. Thirdly, the doctrine incorporates the principle of equality: a notion which Jennings concedes is as vague as that of the rule of law itself. Moreover, and of prime importance, the rule of law implies the notion of liberty (Jennings, 1959, p. 48).

The rule of law is an aspect of ancient and modern natural law thought. In essence, the natural law tradition of which there are many strands insists that the authority of law derives not from the power of any political ruler, but from a higher source, either theological or secular. The laws of man must be evaluated against the dictates of this higher form of law. It is impossible to provide more than a mere sketch of the rich history of natural law in Western philosophy and political thought and the legacy it gives to modern constitutions. Nevertheless, a basic understanding of its nature and evolution is instructive, for it reveals the manner in which the requirements of good law (i.e. morally worthwhile law) have been stipulated over centuries. Aristotle stated in The Politics that the rule of law is preferable to that of any individual. The appeal to law as a control over naked power has been apparent throughout history. At a philosophical level, the natural law tradition, whether theological or secular, instructs that the power of man is not absolute, but is rather controlled and limited by the requirements of a higher law. To the ancient Greeks, man was under the governance of the laws of nature (i.e. the natural forces which controlled the universe) although this view is more closely aligned to the law of nature than natural law as it came to be understood in later wards. However, from the time of Socrates, Plato (427347 BC) and Aristotle (384-322 BC), the quest for virtue/goodness or justice under the law has been a recurrent theme. Socrates, as a teacher and philosopher, was accused, tried and convicted by the grand jury of Athens for corrupting youth with his teachings. Despite the possibility of escape, Socrates chose to accept the verdict of death which had been imposed upon him, in order to demonstrate his fidelity to law. When pressed by Crito to escape, Socrates considered the questions which would be put to him by the laws and constitution of Athens were he to succumb to the temptation to escape the penalty of the law: Can you deny that by this act which you are contemplating you intend, so far as you have the power, to destroy us, the laws, and the whole state as well? Do you imagine that a city can continue to exist and not be turned upside down, if the legal judgments which are pronounced in it have no force but are nullified and destroyed by private persons (Hamilton \& Cairns, 1989, p. 50)?

It is from ancient Greek philosophy that natural law enters into Roman law. From the Corpus Juris Civilis (AD 534) are derived Jus civilis, Jus gentium and Jus naturale. Jus civilis denotes the law of the state; Jus gentium the law of nations; and Jus natuarale a law which expresses a higher and more permanent standard. It is the law of nature (Jus naturale) which corresponded good and equitable. When we read the American or the French Declarations we know that we are confronted with a complete architecture, about the style of which there can be no mistake. It is a political philosophy based upon a particular notion of the individual, of society and of their mutual relationship. It is from these beginnings that the theories of social contract and the rights of man derive. The writings of John Locke, Jean-Jacques Rousseau and Thomas Paine are all infused with the doctrine of the inalienability of individual human right that transcend the law of the state, which cannot be overridden by the state, and which affirm the supremacy of the law of the state is in compliance with natural law (Locke, 1690). 


\section{Marxist View}

Arguments against a formalistic perception of the rule of law adopted by, inter alia, Dicey and Von Hayek present a formidable target for attack from a Marxist perspective. Where liberalism insists that law is neutral as between persons and classes and favors maximum liberty for all under the law, Marxism insists that law represents the interests of the powerful within society. Law is an ideological device engaged by those with power to mask the reality of that power in society, and the correlative powerlessness of the ordinary citizen. The rule of law is thus portrayed as a means of subterfuge: it is a mere pretence which hides injustice. Marxism stands in opposition to liberalism and yet, paradoxically, seeks as its end result the complete liberty of man. Law, from a Marxist perspective, is the reflection of economic power within society, a power which is used to exploit the powerless. Thus it is that, under capitalism, the worker is not rewarded with the full value of his labor: rather, he receives a price for his labor to which is added production costs and profits and together comprises the final price of a product. The laws which regulate factories and employment terms are all underpinned by the acceptance of the capitalist ideal. Laws which ameliorate the conditions of the poor do not represent as appears at first sight (i.e. real social justice), but rather they represent a calculated means by which the poor are kept compliant within their powerlessness (Cain \& Hunt, 1979, p.74).

Accordingly, the welfare state is but a cynical mask for maintenance of the status quo which defeats the movement towards revolutionary economic and social change. Far from hastening the revolution, the welfare state undermines efforts to create working class solidarity. By preventing the fullest development of the material degradation of the working class and by providing a limited immunity from the degradation of the working class and by providing a limited immunity from the vicissitudes of economic crises, a welfare state delays the formation of class conscious and thus prevents a revolutionary situation from arising (Collins, 1982, pp. 126-127). Whether law serves to oppress or merely to uphold the economic status quo and there exists dispute on his matter between Marxists themselves (i.e. law, from a Marxist perspective) does not serve the interests of all in society. The rule of law thus becomes a grand slogan under which is hidden the reality of oppression and absence of liberty. The capitalist's insistence on the rule of law is seen as a fetishism which must be removed along with economic oppression. Only when the capitalist system breaks down, and the law which serves it 'withers away', will society become truly free. When that occurs, there will be no need for law and man will achieve true freedom.

\section{Joseph Raz's View}

Joseph Raz approaches the rule of law from a morally neutral but conceptual standpoint, and asserts that:

The rule of law is a political ideal which a legal system may lack or may possess to a greater or lesser degree. That much is common ground. It is also to be insisted that the rule of law is just one of the virtues which a legal system may possess and by which it is to be judged. It is not to be confused with democracy, justice, equality (before the law or otherwise), human rights of any kind or respect for persons or for the dignity of man. A non-democratic legal system based on the denial of human rights, on extensive poverty, on racial segregation, sexual inequalities, and religious persecution may, in principle, 
conform to the requirements of the rule of law better than any of the legal systems of the more enlightened Western democracies (Collins, 1982, p. 211).

Raz acknowledges that his claim will alarm many, but insists that it presents a coherent view of one important virtue which legal systems should possess. In seeking to elucidate the ideal of the rule of law, Raz draws the analogy between the rule of law and a knife. One quality of a good knife is sharpness. However, the quality of sharpness says nothing as to the use to which the knife might be put: beneficial surgery or murder. Sharpness is morally neutral. And thus it is with the rule of law (Collins, 1982, p.78).

However, the purpose of law is to enable citizens to live within the law. Accordingly, there are certain principles that must be respected if that goal is to be fulfilled. For the rule of law to exist in society, certain qualities must be present. The law must be clear if it is to be capable of being obeyed.

The Law must be publicized in order that citizens are aware of its demands; reasonably stable in order that citizens can plan their lives according to law; prospective so that the law does not require the impossible; non-contradictory for the same reason, and, in addition, the courts must be accessible and staffed by an independent judiciary. Compliance with each of these requirements will indicate that a society respects the rule of law. To make such a statement is not to say that the legal system is one which is necessarily morally good. As seen in Rax's illustration with the quality of sharpness in relation to the knife, the fact of sharpness does not dictate the morality of the purposes to which the knife will be put. It is possible, accordingly, for the rule of law to exist without the legal system necessarily pursuing morally good ends.

\section{Lon Fuller's View}

The writing of Professor Lon Fuller (1964) stands in contrast to Joseph Raz's View may be invoked here in order to develop further this idea. Fuller's focus is on the morality of law For Fuller, the requirements of law, which are substantially the same as those of Raz; lay down the basic minimum requirements, not just of a system in accordance with the rule of law, but for the very existence of a system to which he would accord the label legal. These basic prerequisites form the morality of duty or inner morality of law. These principles provide the basic foundations of a legal system. To draw an analogy with building construction, failure to lay sound foundations will result in the edifice resting on an insecure and fragile base. In addition to a secure foundation, for a legal system to be worthy of recognition and to impose the duty of obedience upon its members, it must serve the needs of the people. Law does not exist in a vacuum separate from the society it regulates. Recognition of this vital characteristic of law demands that the legal system be directed towards altruistic, beneficial ends. This is the morality of aspiration towards which each valid legal system must strive. Thus, a government must seek to provide the environment in which each citizen may realize to his maximum potential the rational plan of life to which he aspires. Society must be free and directed to the good of each of its members. Any government which fails in a material degree to meet these requirements may fail to deserve the label of a legal system. The important point here is that Fuller is quite prepared to argue that a system of government which contravened the basic requirements of a good system of law might be recognized as some form of governmental regime but would not be a government according to law, and hence would not be legal system. In order to deserve recognition as a system of law, the system must respect the very fundamental moral requirements which Fuller identifies. 


\section{Friedrich Von Hayek's View}

A further perspective of the rule of law is provided by Friedrich Von Hayek. The Road to Serfdom was written against the background of the Second World War, and expressed Hayek's fundamental concern with the prospect of the expansion of the state. This von Hayek opposed, other than at a basic level necessary to guarantee freedom. In this connection, Hayek describes, stripped of all technicalities this means that government in all its action is bound by rules fixed and announced before hand that make possible to foresee with fair certainty how the authority will use its coercive powers in given circumstances, and to plan one's individual affairs on the basis of this knowledge (Hayek, 1944, p. 54).

The idea of a welfare state and the entailed notion of distributive justice which entails the state operating under discretionary rules in order to provide a minimum stand of living were firmly opposed by Hayek. The rule of law for Hayek should be confined to the provision of clear, certain rules which would enable people to plan their lives in a free society. To require that people should contribute to the less well off in society through a system of graduated taxation, coupled with discretion to determine entitlement and quantum of recipients, violated his perceived ideal state. Modern expression of many of Hayek's ideas is to be found in the writings of Robert Nozick, a clear and forceful advocate of the minimal state. Nozick rejects any concept of distributive justice. Instead, he argues for perceptions of justice based on the concept of rights expressed in the name of entitlements. A state of affairs and hence a state will be just if it respects the principle of entitlement. As Nozick argued, things come into the world already attached to people having entitlements over them. From the point of view of the historical entitlement conception of justice in holdings, those who start afresh to complete to each according his treats objects as if they appeared from nowhere, out of nothing (Nozick, 1974, p. 160). Justice therefore lies in the recognition of the justice of holdings. If the manner in which property is acquired is lawful, if the manner in which property is transferred is lawful, the society will be just. To deny the justice of this situation from a Nozickian perspective and to argue for the forced redistribution of wealth in society is to defeat the rights of the individual property holder.

\section{John Rawls's Theory of Justice}

Opposed to Hayek and Nozick stands, John Rawl's theory provides a detailed exposition of, and justification for, the interventionist state committed to distributive justice. In essence, a society will be just if it is organized according to principles established by all its members in the original position behind a veil of ignorance. Suffice to note here that the original position and veil of ignorance relate to a stage of decision making about constitutional arrangements wherein the participants know nothing of their own personal attributes and wants and little of the society in which they live. They will accordingly choose principles of justice which are not self-interested but based on maximizing the position of those persons who are in the least enviable position in society. The principles they will choose will be, first, the priority of liberty for all, subject to the need to redistribute goods in society in order to improve the lot of the worst off. The rule of law, according to Rawls (1999), is obviously closely related to liberty. Rawls calls for the regular and impartial administration of public rules which is the essence of a just legal system characterized by the legitimate expectations of the people. Several requirements must be met: rules of law must only command action which is possible; those who enact laws must do so in good faith; like cases must be treated alike. Echoing Dicey, Rawls states that there 
is no offence without a law (nulla poena sine lege) and this requirement in turn demands that laws be known, that they be general, and that penal laws should not be retroactive to the disadvantage of those to whom they apply. Finally, the legal system must respect the dictates of natural justice.

John Rawls concedes a right to disobedience in pursuit of changing a society's sense of justice, but confines civil disobedience to peaceful protest. Rawl's thesis is founded on the notion of social contract. That concept, as has been seen above, involves the mutual recognition, inter alia, of the rights of citizens and the rights of the state. The extent to which citizens participate in the law making process is critical to an understanding of the extent to which there exists an obligation to obey the law. Participation in the democratic process may, however, be used as a means to deny any right to disobey. That is to say, it may be argued that democratic participation implies the individual's acceptance of all laws within the state. Here we must consider what it is that citizen's consent to when electing a government. It seems implausible to argue that we each consent to every action of government throughout a possible five year term of office, irrespective of its merits. However, Professor Plamenatz states that when a vote is cast, you put yourself by your vote under an obligation to obey whatever government comes legally to power under the system, and this can properly be called giving consent. For the purpose of an election is to give authority to the people who win it and if you vote, knowing what you are doing and without being compelled to do it, your voluntarily take part in the process, which gives authority to those people (Plamenatz, 1963, p. 239). This argument surely is contentious and represents a very limited view of the requirement that a government should have moral authority to govern.

Richard Wasserstom (1963) argues that, by participatory democratic process, a prima facie obligation to obey law is imposed, but this prima facie duty can be overridden by the demands of conscience. The appropriate response of the state to acts of civil disobedience is a difficult matter. Ronald Dworkin, for example, argues for official tolerance in the face of dissent and law breaking which is undertaken in pursuit of rights even where violence is employed. Dworkin argues that the state should act with caution in prosecuting civilly disobedient acts. First, the state should respect the stand taken in the defense of rights, even if that stand should prove misguided when the matter ultimately comes before the Supreme Court for a ruling on the validity of the contentious legislation. The decision to prosecute should be decided on the basis of utilitarianism; the doctrine which assesses the justification for a particular action according to the overall increase in the sum of benefit to society as a whole. As Further, on same doctrine Dworkin states that utilitarianism may be a poor general theory of justice, but it states an excellent necessary condition for just punishment. Nobody should ever be punished unless punishing him will do some good on the whole in the long run all things considered (Dwrkin, 1986, p. 114). By prosecuting disobedience to law, the state upholds the positive law and reinforces it. On the other hand, in prosecuting, the state may reveal the defects in the law and may be seen to be enforcing that for which there exists little or no popular support.

\section{A.V. Dicey's View}

In Introduction to the Study of the Law of the Constitution, AV Dicey offered a prosaic description of the rule of law. Here, there are none of the ringing proclamations of the theological or political philosophers. Nevertheless, Dicey's views have continued to exert their influence, despite many challenges, and it is this influence which requires examination. Dicey argued that the rule of law 
in its practical manifestation has three main elements. (I) No man is punishable or can be lawfully made to suffer in body or goods except for a distinct breach of law established in the ordinary legal manner before the ordinary courts of the land. In this sense, the rule of law is contrasted with every system of government based on the exercise by persons in authority of wide, arbitrary, or discretionary powers of constraint. (II) No man is above the law; every man and woman, whatever be his or her rank or condition, is subject to the ordinary law of the realm and amenable to the jurisdiction of the ordinary tribunals. (III) The general principles of the constitution (as, for example, the right to personal liberty, or the right of public meeting) are, with us, the result of judicial decisions determining the rights of private persons in particular cases brought before the courts (Dicey, 1959, pp. 188-195).

The first element of Dicey's highlighted self-explanatory analysis on rule of law. It requires that no one be punished except for conduct which represents a clear breach of law (The principle of nulla poena sine lege). Designed to deny to governments any right to make secret or arbitrary laws, or retrospective penal laws, and to limit the discretionary powers of government, the rule protects the individual. In order to comply fully with this requirement, laws should be open and accessible, clear and certain. In part, this idea ties in with that of the social contract and the reciprocal relationship between the state and the individual. Under social contract theories, the individual citizen transfers his autonomous individual rights to the government, to be held by that government on trust. To express the matter differently, the citizen owes allegiance to the head of the state in return for which he is under the protection of the sovereignty. The doctrine of allegiance incorporates the idea of obedience to law on the part of the citizen and government. Laws which are arbitrary or secret are incapable of justification on the basis of the mandate of the people and, accordingly, offend against the reciprocal relationship on which constitutional democracy depends. Where there is a form of granting power to a minister of the state to act as he thinks fit on civil servants administering the social welfare system, it will be impossible for the individual to know what rights he or she has. Moreover, the delegation of broad discretionary power (i.e. albeit on the authority of the sovereign parliament) renders such power difficult, if not impossible, to challenge before a court of law or other adjudicatory tribunal. Perhaps no rule of construction is more firmly established than this, that a retrospective operation is not to be given to a statue so as to impair an existing right or obligation, otherwise than as regards matters of procedure, unless that effect cannot be avoided without doing violence to the language of the enactment. If the enactment is expressed in language which if fairly capable of either interpretation, it ought to be construed as prospective only (Wright, 1987, pp. 551-52). The evidence for the notion of equality before the law is neither clear nor in contentious. As with so much of the constitution, there remains room for doubt and argument. Nevertheless, it is submitted that there exists sufficient evidence to suggest that Dicey's approach remains a fruitful avenue for inquiry and exploration. To dismiss as some writers do this aspect of Dicey's exposition of the rule of law, is to deprive the student of the constitution of a valuable tool for analysis.

The second element of Dicey's emphasizes role of government maintaining equality on law and order in which everyone, irrespective of rank, whether official or individual, shall be subject to the law (Zellick, 1985, p. 283). Dicey viewed the French system of special courts to deal with complaints against government as abhorrent, fearing that specially constituted courts would unduly favor the government over the citizen. Dicey has often been interpreted as requiring that there be actual equality 
in terms of legal rights, powers and capacities. Such an interpretation is, however, misguided. The idea of equality before the law, irrespective of status, is subject to so many exceptions that the statement is of doubtful value. In so far as equal powers are concerned, it must be recognized that the police have powers over and above the citizen under common law and the Police and Criminal Evidence Act, 1984 in England. That ministers have power to enact delegated legislation (but subject to parliamentary approval), that the government enjoys immunities under the law, that the government acting in the name of the state may exercise powers which may defeat the rights of individuals, Malone v Metropolitan Police Commissioner (1979), in England that members of Parliament, and that diplomats enjoy immunities not available to citizens. And, as Sir Ivor Jennings points out, no two citizens are entirely equal: pawnbrokers, money lenders, landlords, drivers of motor cars, married women, and indeed most other classes have special rights and duties. Against this catalogue, which is not exhaustive, must be set the extent to which government and public officials are subject to law in the sense of being accountable for their actions before the ordinary courts, for this, indeed, was Dicey's real argument. The doctrine acknowledges the need of a consistent application of the law irrespective of status. No one is immune from criminal prosecution (Zellick, 1985, p. 11). Hence, official accountability to law is one of the foundations of the foundations of the rule of law.

The third element of Dicey's reveals his preference for common law protection of human rights over and above a specially formulated code of rights, thus demonstrating a faith in the judiciary which is not sustainable nowadays. Evaluation of this aspect of the definition must await analysis of the human rights and the scope of the protection which it gives to individual citizens. Accordingly, citizens no longer have to undertake the lengthy process of applying to the Court of Human Rights in Strasbourg, but are able to seek a remedy in the domestic courts. The method of incorporation adopted, however, falls far short of enabling the judges to invalidate or set aside domestic legislation. Instead, the judges of the higher courts are empowered to make declarations of incompatibility with convention rights. Once such a declaration had been made, it remains for parliament to approve an amendment to the law. As a result, the Human Rights Act, far from elevating individual rights proclaimed in the convention to a higher status than statute, preserves Constitutional sovereign law making and amending power, and also maintains the separation of powers.

\section{Conclusion}

The ideas of political philosophers indicate accountability and responsibility of the government for maintain rule of law. Rule of law means both according to the legal rules and something over and above purely formal legality and imputes the concepts of legitimacy and constitutionality. In its turn, legitimacy implies rightness or morality of law to govern just society. The law is not autonomous but rests on the support of those it governs. The law is the servant of the sense of rightness in the society, and whilst the rule of law places law and order above every individual, irrespective of rank and position that remains, paradoxically, subject to the ultimate judgment of the citizens.

\section{References}

Aristotle (1962). The Politicsof Aristotle (7th ed.). London: Oxford University Press.

Cain, M. \& Hunt, A. (1979). Marx and Engels on Law. London: Academic.

Collins, H. (1982). Marxism and Law. Oxford: Clarendon.

Dicey, A. V. (1859). Introduction to the study of the constitution (10th eds.). London: Macmillan.

NUTA JOURNAL, 5 (1\&2), 2074 : ISSN: 2616 - 017x 
Dwrkin, R. (1986). A matter of principle. Oxford: Princeton Up.

E. Hamilton \& H. Cairns (Eds.) (1989). Plato's Collected Dialogues. New Jersey Princeton Up. Hayek, F. V. (1944). The road to sarfdom.

Barnett, H. (2004). The Constitutional and Administrative Law. London: Cavendish Publishing. Jennings, I. (1959b). The Law and the Constitution. London: Hodder and Stoughton.

Locke, J. (1690). An Essay Concerning Humane Understanding (1st ed.). London: Thomas Bassett, 16

Lustgarten, R. (1988). Socialism and the Rule of Law. Journal of Law and Society, 15 (25)

Nozick, R. (1974). Anarchy, State and Utopia. Oxford: Blackwell Publication.

Plamenatz, J. (1963). Man and society. New York, Volume I, p.239.

Raz, J. (1979). The Authority of Law. Oxford: OUP

Rawls, J. (1999). A Theory of Justic (Revised edition.). London: Oxford Up.

Shklar, R. (1987). 'Political theory and the rule of law'. In K. Hutchinson, \& P. Monahan (Eds.), The Rule of Law; Ideal or Ideology Toronto: Creswell.

Wright, P. (1987). Spycatcher: The candid Auto by ogiaphy of a senior intelligence officer. New York: Viking.

Zellick, G. J. (1985). Government Beyound Law. 